\title{
A dendroecological reconstruction of western spruce budworm outbreaks (Choristoneura occidentalis) in the Front Range, Colorado, from 1720 to 1986
}

\author{
Urs M. Weber ${ }^{1, *}$, Fritz H. Schweingruber ${ }^{2}$ \\ ${ }^{1}$ Institute of Botany, University of Base1, Schönbeinstrasse 6, CH-4056 Basel, Switzerland \\ 2 FSL Swiss Federal Institute for Forest, Snow and Landscape Research, CH-8903 Birmensdorf, Switzerland
}

Received: 2 April 1993 / Accepted: 27 July 1994

\begin{abstract}
Radial increment cores from Douglas-fir (Pseudotsuga menziesii) and blue spruce (Picea pungens), defoliated by western spruce budworm (Choristoneura occidentalis), were analyzed by means of dendrochronological methods and compared with cores from undefoliated ponderosa pine (Pinus ponderosa) and lodgepole pine (Pinus contorta) growing on the same sites in the Front Range, Colorado. Extensive deforestation during the gold and silver booms in the second part of the nineteenth century led to dense and almost pure stands of shadetolerant budworm host species. By using the skeleton plot method, the number of trees with clear growth reductions is obtained, thus representing an exact record of forest insect attacks. The analysis of abrupt growth reductions revealed at least nine outbreaks of western spruce budworm between 1720 and 1986, the majority occurring in the nineteenth century. The outbreaks were graphically compared with periods of attack in New Mexico and Colorado which were detected by other scientists employing tree-ring measurement techniques. No increase in the frequency of severe outbreaks during the twentieth century was observed, yet there is some evidence that the most recent outbreak might be the most severe ever recorded. Open Douglas-fir stands on higher sites were more susceptible to heavy budworm attack than dense stands on lower sites. Blue spruce was less frequently and less severely attacked than Douglas-fir. The spatial pattern of historical outbreaks generally was very patchy.
\end{abstract}

Key words: Douglas-fir - Western spruce budworm Dendrochronology - Front Range - Abrupt growth reduction

* Present address: Swiss National Museum, Department of Research and Development, Hardturmstrasse 181, CH-8005 Zürich, Switzerland

Correspondence to: U. M. Weber

\section{Introduction}

Trees usually react to insect attack with abrupt growth reductions. Many studies have demonstrated the negative effect of forest insect outbreaks on radial growth by using dendrochronological methods, e.g. Hildahl and Refks (1960) on Malacosoma disstria, Vins and Materna (1969) on Lymantria monacha, and Schwenke (1978) on Tortrix viridiana.

Several studies deal with issues related to rhythmic or periodic outbreaks. Geer (1975), Schweingruber (1979) and Pignatelli and Bleuler (1988) reconstructed the cyclic outbreaks of Zeiraphera diniana in two alpine valleys over the last 700 years. Filion et al. (1993) showed that Pristiphora erichsonii periodically has affected Larix laricina in northern Quebec since the beginning of the nineteenth century. According to Christensen (1987) the 3-, 4-, and 5-year cycles of infestations of Melolontha melolontha are reflected in ring-width growth of European oaks. Several outbreaks of Epirrita autumnata on Betula pubescens at the northern timberline of Scandinavia over the past 200 years have been reconstructed (Eckstein et al. 1990).

The relationship between outbreaks of Choristoneura sp and radial growth of several conifer species has been extensively studied, mainly by Blais $(1962,1965,1983)$ on Abies balsamea and Picea glauca, Swetnam (1986) on Pseudotsuga menziesii and Abies concolor, Swetnam and Lynch (1989) on Pseudotsuga menziesii, and Morin and Laprise (1990) on Abies balsamea and Picea glauca. All of these authors tried to relate recent spruce budworm outbreaks to the intensities and frequencies of historical outbreaks by using classic dendrochronological techniques. Ring-width measurements of many host tree samples were averaged to construct ring-width chronologies and these were compared with ring-width chronologies of nonhost trees growing at the same location. This method clearly emphasizes the intensive outbreaks. However, outbreaks that are visible in only a few trees may be averaged out of mean ring-width series. Thus, these procedures do not allow the precise dating of the initial year of an 


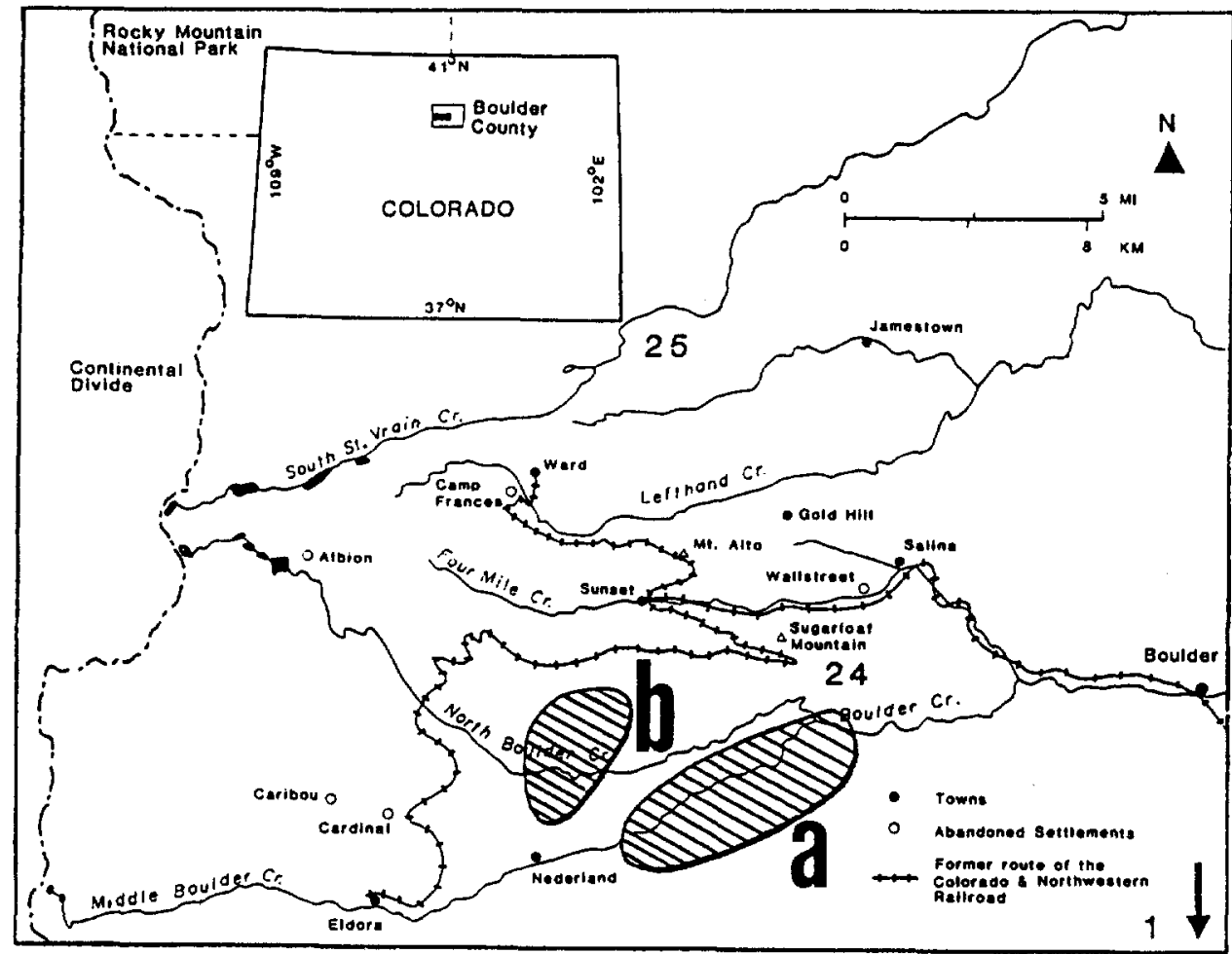

Fig. 1. The study area on the eastern slope of the Front Range near Boulder, Colorado. Map after Veblen and Lorenz (1986). Sub-area (a): Boulder Canyon 2060-2550 m.a.s.l. (meters above sea-level). Sub-area (b): Peak to Peak Highway $2485-2660$ m.a.s.l. 1,24 and $25=$ sites outside the two main study areas outbreak, because its beginning is usually not concentrated in one year. To avoid these disadvantages, we used the skeleton plot method (Douglass 1941) which highlights the beginning of abrupt growth changes as well as their duration. In contrast to ring-width measurements it also shows the exact number of affected trees in any specific year. However, this visual method requires that abrupt growth reductions exceed a $40 \%$ threshold, and abrupt growth releases a $150 \%$ threshold (Schweingruber et al. 1986).

A major goal of this study was to test if the modified skeleton plot method (Schweingruber et al. 1990) allows identification of past forest insect infestations. We compared samples from ecologically different sites in order to find relationships between local ecological site conditions, historical deforestations and the frequency and intensity of western spruce budworm outbreaks. A comparison was made with outbreaks identified by Swetnam and Lynch (1989) in New Mexico and Colorado in order to test for possible correspondences in fluctuations of budworm populations over large areas.

\section{Materials and methods}

The study sites were located on the eastern slopes of the Front Range near Boulder, Colorado, between 2060 and $2660 \mathrm{~m}$ on soils derived from granite bedrock. The mean annual precipitation ranges from $1000 \mathrm{~mm}$ on Niwot Ridge at $3500 \mathrm{~m}$ to $460 \mathrm{~mm}$ in Boulder at $1600 \mathrm{~m}$ (Callahan 1986). Strong winds affect the vegetation throughout the year, especially at the upper timberline. During the gold and silver booms, from 1859 until the beginning of the twentieth century, virgin forests were either extensively logged or burned (Veblen and Lorenz 1986).
Except for three sites the study material was collected from two sub-areas (Fig. 1):

Sub-area A, Boulder Canyon. From Nederland in a NE direction down to Boulder.

The dry south-facing slope is characterized by open stands of ponderosa pine (Pinus ponderosa), interspersed with Rocky Mountain juniper (Juniperus scopulorum) and a few Douglas-fir (Pseudotsuga menziesii). Prickly pear (Opuntia phaeacantha) is typical. Moister north-facing slopes are covered with mostly dense stands of Douglasfir and lodgepole pine (Pinus contorta). Ponderosa pine is more common on the comparatively xeric upper slope; as the environment moistens further down the number of blue spruce (Picea pungens) increases. The moistest flat sites are occupied by mixed stands of Douglas-fir and blue spruce with an occasional ponderosa pine. Broadleaf trees such as quaking aspen (Populus tremuloides), Rocky Mountain maple (Acer glabrum), bog birch (Betula glandulosa), and willow (Salix sp) are very common as well. Reed (Phragmites australis) is typical.

Sub-area B, Peak to Peak Highway. A mountainous area north of Nederland along the Peak to Peak Highway.

On dry sites of S to SE aspects mixed stands of Douglas-fir and ponderosa pine dominate. On moister sites of $\mathrm{N}$ to $\mathrm{NW}$ aspects there are mainly either pure Douglas-fir stands or mixed stands of Douglasfir and lodgepole pine. At higher elevations $(>2500 \mathrm{~m})$ isolated individuals of limber pine (Pinus flexilis) can be found. Quaking aspen is the most common broadleaf tree. As a pioneer species it inhabits clearings.

A total of 580 increment cores were taken from 25 sites during the growing season of 1986: 366 Douglas-fir cores from 22 sites, 98 blue spruce cores from 8 sites, 92 ponderosa pine cores from 8 sites, and 24 lodgepole pine cores from 2 sites (Table 1).

Sites were selected based on the representativeness of the forest, on the variation of topographic position and composition of vegetation within each sub-area (all sites were phytosociologically defined after Braun-Blanquet (1964). The soil moisture capacity was estimated after 
Table 1. Study sites

\begin{tabular}{|c|c|c|c|c|c|c|c|c|c|c|}
\hline Area & Site & $\begin{array}{l}\text { Altitude } \\
\text { (m) }\end{array}$ & $\begin{array}{l}\text { Soil } \\
\text { conditions }\end{array}$ & Characteristic speciesi & Aspect & $\begin{array}{l}\text { Slope } \\
\operatorname{dip}\left({ }^{\circ}\right)\end{array}$ & \multicolumn{4}{|c|}{ Number of cores } \\
\hline Coal Creek & 1-ZUG & 2150 & vde & Opuntia sp & SE & 45 & 23 & & & \\
\hline \multicolumn{11}{|l|}{ Canyon } \\
\hline Boulder & 2-MIN & 2425 & $\mathrm{mg}$ & Acer glabrum & NW & 25 & 12 & & & \\
\hline Canyon & $\begin{array}{l}\text { 3-SUD } \\
\text { 4-RAN } \\
\text { 5-STE } \\
\text { 6-FAL } \\
\text { 7-LOG } \\
\text { 8-PON } \\
\text { 9-NOR } \\
\text { 10-FEL } \\
\text { 11-STA } \\
\text { 12-PIC }\end{array}$ & $\begin{array}{l}2140 \\
2350 \\
2120 \\
2060 \\
2300 \\
2550 \\
2520 \\
2490 \\
2480 \\
2400\end{array}$ & $\begin{array}{l}\mathrm{vd} \\
\mathrm{df}^{\mathrm{f}} \\
\mathrm{m} \\
\mathrm{moh} \\
\mathrm{mo} \\
\mathrm{d} \\
\mathrm{m} \\
\mathrm{m} \\
\mathrm{m} \\
\mathrm{mo}\end{array}$ & $\begin{array}{l}\text { Opuntia sp } \\
\text { Purshia tridentata } \\
\text { Acer glabrum } \\
\text { Alnus tenuifolia } \\
\text { Phragmites australis } \\
\text { Artemisia tridentata } \\
\text { Acer glabrum } \\
\text { Senecio triangularis } \\
\text { Linnaea borealis } \\
\text { Equisetum arvense }\end{array}$ & $\begin{array}{l}\text { S } \\
\text { NNE } \\
\text { N } \\
\text { Flat } \\
\text { Flat } \\
\text { SW } \\
\mathrm{N} \\
\text { SW } \\
\text { NW } \\
\text { flat }\end{array}$ & $\begin{array}{l}40 \\
5 \\
45 \\
0 \\
0 \\
20 \\
15 \\
20 \\
10 \\
0\end{array}$ & $\begin{array}{l}16 \\
12 \\
18 \\
12 \\
12 \\
16 \\
36 \\
16 \\
15\end{array}$ & $\begin{array}{l}12 \\
12 \\
12\end{array}$ & $\begin{array}{l}11 \\
12\end{array}$ & 12 \\
\hline & 16-HU3 & 2485 & $\mathrm{~m}$ & Lonicera involucrata & $\mathrm{N}$ & 30 & 12 & 12 & & \\
\hline & 17-LAK & 2545 & $\mathrm{~d}$ & Artemisia tridentata & $S$ & 10 & 12 & & 12 & \\
\hline & 18-WES & 2580 & d & Purshia tridentata & W & 20 & 16 & & & \\
\hline & 19-OST & 2620 & d & Purshia tridentata & E & 10 & 12 & & 12 & \\
\hline & 20-RAC & 2580 & d & Purshia tridentata & $\mathrm{W}$ & 20 & 16 & & & \\
\hline & 21-SN1 & 2660 & $\mathrm{~d}$ & Sedum $s p$ & flat & 0 & 12 & & 12 & \\
\hline & $22-\mathrm{SN} 2$ & 2630 & $\mathrm{~d}$ & Ribes cereum & flat & 0 & 12 & & & \\
\hline & 23-MOO & 2645 & mo & Salix $s p$ & flat & 0 & & 12 & & \\
\hline Sugarloaf & 24-SUG & 2605 & d & Eriogonum umbellatum & SE & 30 & 12 & & 11 & \\
\hline \multicolumn{11}{|l|}{ Mountain } \\
\hline $\begin{array}{l}\text { St. Vrain } \\
\text { Creek Canyon }\end{array}$ & 25-RIV & 2180 & $\mathrm{~m}$ & Tellima grandiflora & NW & 10 & 12 & & & \\
\hline
\end{tabular}

a P.m. = Douglas-fir

b P.p. = blue spruce

c P.po. = ponderosa pine

d P.co. = lodgepole pine

e vd = very dry

f $d=$ dry $\mathrm{g} \mathrm{m}=$ medium

h mo $=$ moist

j Only species that are characteristic for hydrological conditions of sites are listed (Landolt 1977)
Landolt 1977) on budworm infested host trees, and on the presence of non-host trees in or close to (within $500 \mathrm{~m}$ ) the selected stands.

At least 12 dominant or codominant host trees (Douglas-fir and/or blue spruce) exceeding approximately $20 \mathrm{~cm}$ diameter at breast height (approx. $1.37 \mathrm{~m}$ above ground level) were selected within an area of $500-1000 \mathrm{~m}^{2}$ at each site. No samples were taken from dead trees because the current outbreak would have been overemphasized compared to past outbreaks which were only represented by surviving trees. One increment core per tree was extracted at breast height. On slopes the cores were taken on the upslope side of the trees to avoid the influence of compression wood. In addition, samples of at least 10 non-host trees (ponderosa or lodgepole pine) were either taken inside the site or in pure non-host stands not more than $500 \mathrm{~m}$ from the site centre.

All increment cores were cross-dated using the skeleton plot method (Douglass 1941) in order to identify ring anomalies such as missing or false rings. The onset and duration of growth reductions were not determined through ring-width measurements but on the basis of observed conspicuous changes in radial tree growth called 'abrupt growth changes' (Schweingruber et al. 1990). The result is a record which expresses the proportion of affected trees of a population during an outbreak. For each core the tree-ring sequence of average radial growth was determined. Abrupt reductions of $40 \%$ or more and increases of $150 \%$ or more, compared to the four preceeding years, can be recognized with the naked eye. In contrast to Schweingruber et al. (1990) we distinguished five classes of growth reduction in order to identify budworm outbreaks within ring sequences of extreme increment decline as definitely as possible.

Class 1, moderate reduction: $40-50 \%$ growth loss

Class 2, distinct reduction: $51-65 \%$ growth loss

Class 3, strong reduction: $66-80 \%$ growth loss

Class 4 , very strong reduction: $81-90 \%$ growth loss

Class 5, extreme reduction: $91-100 \%$ growth loss

Also in contrast to Schweingruber et al. (1990) we defined a growth reduction as three consecutive narrow rings in order to reconstruct short outbreaks. The first year of such conspicuous ring sequences is called an 'event year', a term which is also used for single rings with extreme positive or negative deviations from average width. Both event years and phases of growth reduction/increase were added up and recorded in 'master plots' for each species and site. This allowed identification of concentrations of synchronous events and phases of reduced/increased growth. Where more than $40 \%$ of the trees from one site displayed an event year in any given year, we called that year a 'pointer year'.

For reasons of clarity, we considered a weighted diagram to be more appropriate for depicting the course of the abrupt growth changes than the conventional diagrams used, for example, by Kontic et al. (1986) or Schweingruber et al. $(1986,1990)$ which display the different classes of abrupt growth reduction/release. Thus, the abrupt growth change values of the single trees were added up per site and 
$\%$ of trees with growth reductions (weighted)
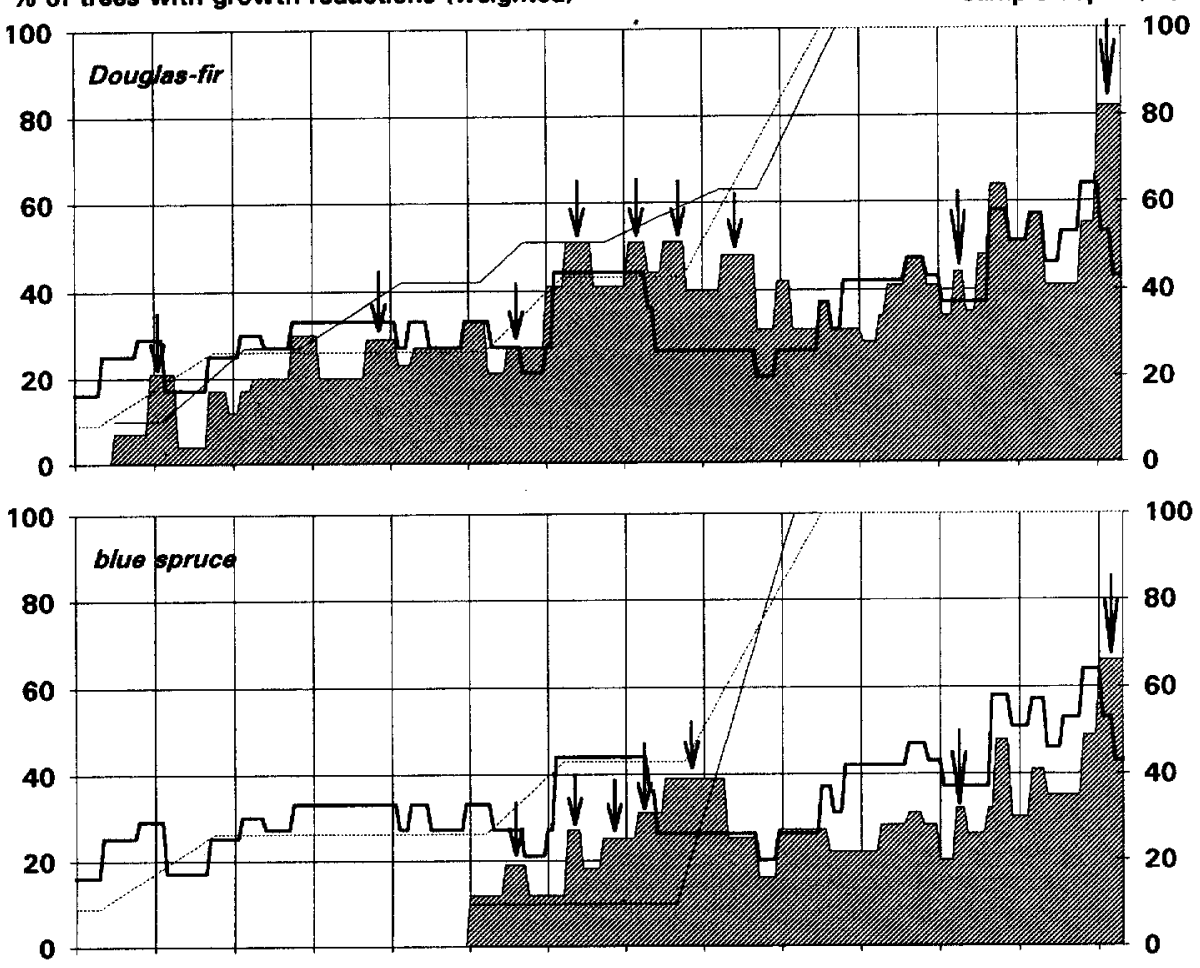

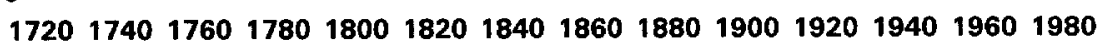

Fig. 2. Reconstruction of western spruce budworm outbreaks (master plot of all 25 sites). Percentage of dominant trees with growth reductions weighted with respect to $n$ and $f=5$ (see Materials and methods for details): Douglas-fir/blue spruce (hosts), — ponderosa pine and lodgepole pine (non-hosts), $\downarrow$ outbreak of the western spruce budworm (long arrow = outbreak verified by US Forest Service records), ... sample depth of hosts in percent (Douglasfir $n=266$, blue spruce $n=98$ ), and --sample depth of non-hosts in percent (ponderosa and lodgepole pine $n=116$ ). The arrows indicate periods in which the host species showed reduced growth while the non-hosts grew normally or were even in a growth release period. Thus, the arrows indicate outbreaks of the western spruce budworm. The length of such a period (year of abrupt growth reduction to year of abrupt growth release or to year of a further increase of growth reduction) is considered to be the duration of an outbreak. The initial year of an infestation equals the year of the abrupt growth decrease in the host tree chronology species and weighted with respect to the maximum class of abrupt growth change and the number of trees available per year according to the formula

$$
A=\frac{\left(\sum * 100\right)}{(f * n)}
$$

$A=$ percentage of trees with abrupt growth changes weighted with respect to $f$ and $n$

$$
\sum_{i=1}^{n}=\text { Sum of the abrupt growth changes per site and species }
$$

$f=$ Weighting factor which equals the maximum class of abrupt growth change $(=5)$

$n=$ number of samples

No information is lost using this weighting procedure regarding the intensity of an abrupt growth change. The calculated values show the percentage of trees which theoretically are in a period of maximum growth reduction/release.

To isolate the effects of western spruce budworm defoliation on tree growth from climatic or anthropogenic effects, ring sequences from host and non-host trees were compared (Swetnam 1986, Swetnam and Lynch 1989). In our study area, ponderosa and lodgepole pine served as non-host species. Swetnam and Lynch (1989) showed that ponderosa pine is a good estimator of Douglas-fir growth. For each site, host and non-host increment sequences were compared graphically. Periods which showed an opposite radial growth of host and nonhost trees were interpreted as budworm phases: radial increment of host trees had to exhibit an abrupt growth reduction while non-hosts showed none or even a growth increase before an outbreak was suspected.

The severity of historical budworm outbreaks cannot be absolutely computed, but the difference between observed and expected radial growth can be estimated (Swetnam and Lynch 1989). With the skeleton plot method it is possible to assess the severity of outbreaks with the before-mentioned five-step classification. Yet, for the comparison of sites, we used three severity classes 'weak', 'strong' and 'no' outbreak in order to avoid a disproportionate interpretation of the data. Weak outbreak: $25-49 \%$ of the host trees exhibit an abrupt growth reduction. Strong outbreak: either $\geq 50 \%$ of the host trees exhibit an abrupt growth reduction of class 1 or 2 , or $\geq 33 \%$ of class 3,4 or 5 , and no outbreak: $<25 \%$ of the host trees exhibit an abrupt growth reduction.

The duration of an outbreak was defined as the period of reduced growth of host trees (year of abrupt growth reduction to year of abrupt growth release or to year of a further abrupt growth reduction).

Other records of western spruce budworm outbreaks in New Mexico and Colorado were obtained by tree-ring measurements (Swetnam and Lynch 1989). Fundamental differences in measurement, computation and presentation between the two methods did not allow for direct comparisons of initial year, period or severity of outbreaks; however, the dates of the outbreaks could be graphically compared.

\section{Results}

\section{Missing rings}

Cross-dating revealed a total of 131 missing rings from 580 tree cores. Although the major part of all absent rings (93\%) appeared in Douglas-fir, only $29.7 \%$ consistently occurred during periods identified as budworm outbreaks. The most distinct 'pointer year' was 1954 , when $16 \%$ of the Douglas-fir samples or $11 \%$ of all analyzed radii showed an absent ring. 1954 was the driest year since 1900 (Callahan 1986). Apart from 1954 most of the missing rings appeared in 1925, 1955 and 1963 in host and non-host samples from exclusively xeric sites. 
Table 2 Reconstructed outbreaks of western spruce budworm per site and species

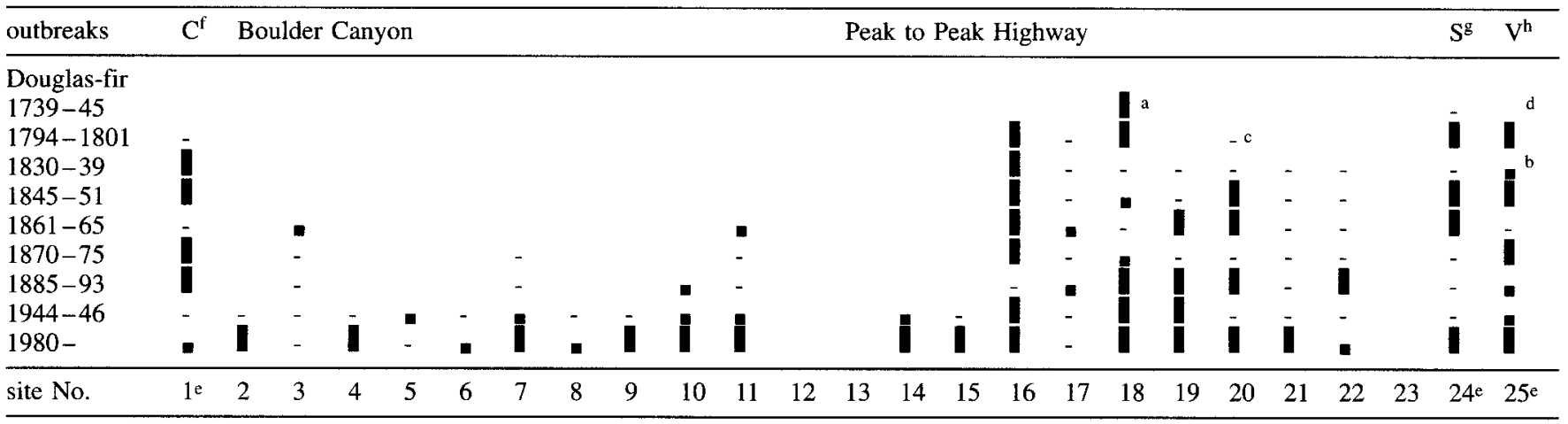

\footnotetext{
blue spruce

$1829-34$

$1845-48$

$1854-62$ ?

$1863-69$

$1870-85$

$1944-46$

$1980-$
}

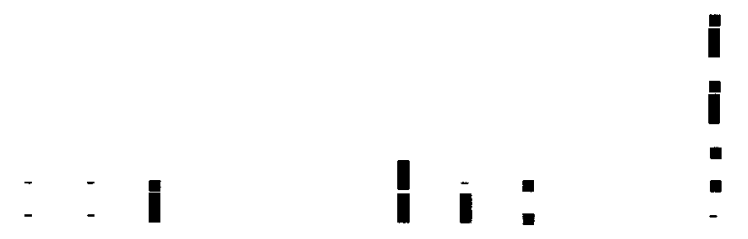

\begin{tabular}{lllllllllllllllllllllllllllll}
\hline site No. & 1 & 2 & 3 & 4 & 5 & 6 & 7 & 8 & 9 & 10 & 11 & 12 & 13 & 14 & 15 & 16 & 17 & 18 & 19 & 20 & 21 & 22 & 23 & 24 & 25
\end{tabular}

a = distinct outbreak, $\geq 50 \%(\geq 33 \%$ ) of host trees exhibit an abrupt growth reduction of class 1 or 2 (class 3, 4 or 5)

$\mathrm{b}_{\mathrm{m}}=$ weak outbreak, $25-49 \%$ of host trees exhibit an aprupt growth reduction

$c_{-}=$no outbreak, $<25 \%$ of host trees exhibit an abrupt growth reduction

d No symbols $=$ no samples

e Sites 1,24 and 25 lie outside the two main study areas.

${ }^{f} \mathrm{C}=$ Coal Creek Canyon, $\mathrm{g} S=$ Sugarloaf Mountain, ${ }^{\mathrm{h}} \mathrm{V}=\mathrm{St}$. Vrain Creek Canyon.

\section{Frequency, duration and severity of outbreaks}

Comparison of the frequency of abrupt growth reductions between the host species (Douglas-fir, blue spruce) attacked by western spruce budworm and the non-host species (ponderosa pine, lodgepole pine) revealed several aperiodic infestation phases (Fig. 2). These two diagrams display the summation of periods with reduced growth of all samples for each species between 1720 and 1986 (blue spruce data from 1820) weighted with respect to the theoretically possible maximum growth reduction (see Materials and methods for details). The percentage of samples per year should be remembered to avoid possible misinterpretation of the data. Likewise it is important to remember that all the study host trees survived past outbreaks. Thus the most severe outbreaks in the past may not be fully represented because the trees which died during an outbreak could no longer be measured.

Defoliation by western spruce budworm usually results in an abrupt growth reduction in host trees while non-hosts either grow normally or show an abrupt growth release.

Budworm outbreaks were analyzed for each host species. Altogether nine outbreaks were identified in 266 Douglas-fir samples, and seven outbreaks in 98 blue spruce samples.

The average interval between initial years of successive outbreaks was 30.1 years (range 9-59 years, SD 19.4 years) for Douglas-fir and 25.2 years (range 7-74 years, SD 16.2 years) for blue spruce.
The average duration of an outbreak was 6.9 years (range 3-10 years, SD 2.2 years) for Douglas-fir and 7.5 years (range 3-16 years, SD 5.2 years) for blue spruce. The values indicate that frequency and duration of outbreaks were highly variable, especially in the blue spruce sequences (see also Table 3).

An increase in the frequency of budworm infestations between 1830 and 1900 is evident, as well as a period of greatly reduced growth of both hosts and non-hosts in the early $1840 \mathrm{~s}$. However, the tree-ring sequences of the two host species did not reveal the same outbreak pattern. The three subsequent outbreaks in blue spruce $(1854,1863$, 1870) followed each other without any growth release in between. Whereas, at the same time, the outbreaks in Douglas-fir were clearly separated by growth recovery. There was only one similar occurrence in Douglas-fir, where no growth recovery followed the 1830s budworm infestation. The 1854 outbreak was only visible in blue spruce, and the 1885 outbreak only appeared in Douglas-fir.

In contrast to the increasing number of outbreaks between 1830 and 1900, the tree-ring sequences before and after this period each exhibited two outbreaks within about 100 years. Thus there is no evidence that the frequency of outbreaks has increased in our century. Nonetheless, both young and old trees showed about the same class of reduction, which might be an indication of an increase in the intensity of the most recent outbreak. A current study on the larch bud moth (Zeiraphera diniana) in the central Swiss Alps (U. Weber, unpublished data) indicates that radial growth of young trees (Larix de- 


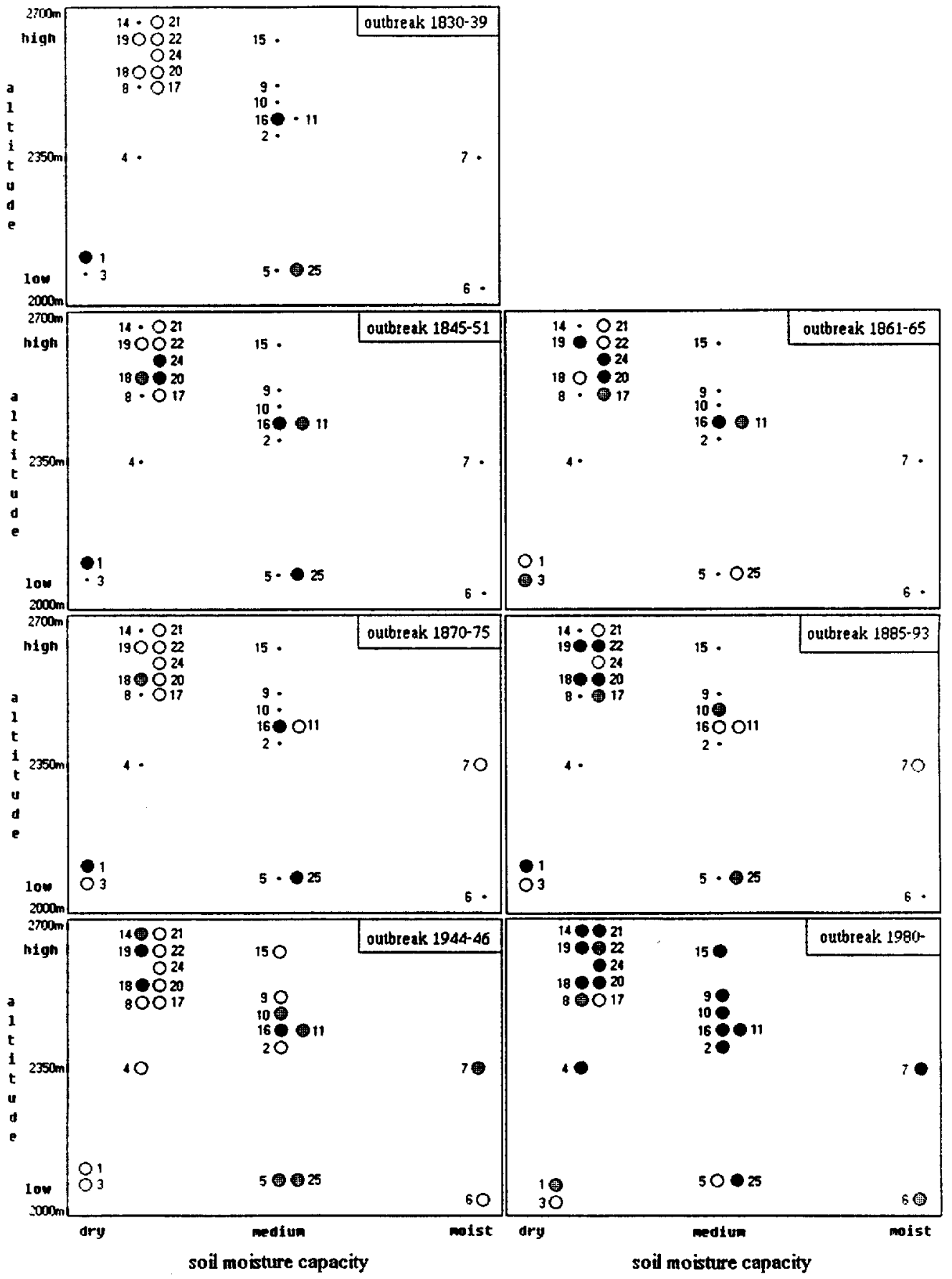

Fig. 3. Outbreaks of western spruce budworm in the 22 Douglas-fir sites subdivided in respect of altitude and soil moisture capacity (three-step classification): strong outbreak, weak outbreak, $O$ no outbreak, and · no samples. The hydrological classification of the sites was determined by phytosociological mapping (Landolt 1977) cidua) is reduced less during an outbreak than radial growth of old trees.

Although some of the host trees demonstrated a growth reduction in 1976, by the definition used earlier, the outbreak began in 1980. By 1985, the outbreak increased further with $23 \%$ of the host trees demonstrating growth reductions.

\section{Ecological pattern of sites and outbreaks}

The outbreaks of western spruce budworm were compiled per study site and host species (Table 2). The long-term effect of the heavy deforestations in the nineteenth century is manifested by the two age classes of the montane forests: most of the stands are either less than 120 years or more than 200 years old. Thus it was not possible to gain information about older budworm infestations from all stands. Most young stands were located in the Boulder Canyon area. 
Table 3. Frequency and duration of western spruce budworm outbreaks in Colorado and New Mexico. For the calculation of the duration the current outbreak data (1980s) were excluded

\begin{tabular}{|c|c|c|c|c|c|c|c|c|}
\hline & \multicolumn{4}{|c|}{ Swetnam and Lynch data $(1700-1960$ s) } & \multirow{2}{*}{\multicolumn{4}{|c|}{$\begin{array}{l}\text { Boulder data }(1730-1980 \mathrm{~s}) \\
\text { Colorado }\end{array}$}} \\
\hline & \multicolumn{2}{|c|}{ New Mexico Douglas-fir } & \multicolumn{2}{|c|}{ Colorado Douglas-fir } & & & & \\
\hline & \multirow[t]{2}{*}{ Mean } & \multirow[t]{2}{*}{$\mathrm{SD}$} & \multirow[t]{2}{*}{ Mean } & \multirow[t]{2}{*}{ SD } & \multicolumn{2}{|c|}{ Douglas-fir } & \multicolumn{2}{|c|}{ blue spruce } \\
\hline & & & & & Mean & SD & Mean & SD \\
\hline $\begin{array}{l}\text { Interval between } \\
\text { initial years of } \\
\text { succesive outbreaks } \\
\text { (years) }\end{array}$ & 34.9 & 13.1 & 36.8 & 17.2 & 30.1 & 19.4 & 25.2 & 16.2 \\
\hline Duration (years) & 13.8 & 6.0 & 11.6 & 5.1 & 6.9 & 2.2 & 7.5 & 5.2 \\
\hline
\end{tabular}

No outbreak was manifested on all research sites, not even the most recent one. Comparatively distinct infestations were found in the 1790s (heavy outbreaks in four out of six stands) and the 1980s (heavy outbreaks in 15 out of 25 stands), while those of the 1830 s ( 2 out of 10 ) and $1870 \mathrm{~s}$ ( 3 out of 13) were relatively weak. A comparison of the two main study areas did not reveal any important differences in the frequency of outbreaks. Most of the stands in the Boulder Canyon area were too young for comparison with older infestations.

Comparing the single sites, a pattern of varied budworm injuries was found. While the stands 16 and 18 were attacked during almost every outbreak, the nearby stands 17,21 , and 22 (the five stands lie within approximately $1 \mathrm{~km}^{2}$ ) were affected during at most two outbreaks (apart from site 16 the soil moisture capacity was low). The following Douglas-fir stands were attacked in less than $50 \%$ of the outbreaks: $3,17,21$, and 22 . Blue spruce stands tended to be small and, as a consequence, often escaped an attack: three out of eight stands were never infested; however, all of them were less than 120 years old. Surprisingly, the blue spruces of site 16 were not affected during the most recent outbreak. Old and young stands were equally defoliated.

In general the pattern of outbreaks was very patchy. One trend, however, is obvious: $80 \%$ of the actual outbreaks in the Douglas-fir stands from the Peak to Peak Highway area were heavy while there were only $37.5 \%$ heavy outbreaks in Boulder Canyon. Thus, heavy insect attacks seem to have predominantly occurred in high elevation stands.

By means of eco-diagrams (Ellenberg 1982) we tried to discover possible relations between the last seven budworm outbreaks in Douglas-fir stands and altitude/soil moisture capacity of the sites (Fig. 3). The soil moisture capacity was defined by means of phytosociological mapping. In the following discussion the 1739-45 and 1794-1801 outbreaks were not considered because they were only represented by two and seven stands respectively. The blue spruce sites were not considered as well for only the last two outbreaks were represented by all sites. The number of stands which potentially may represent an outbreak should always be remembered during interpretation of the data. Unfortunately the two moist sites were represented only by relatively young trees.
Comparing the range of outbreaks in the 22 Douglas-fir stands, no general trend could be observed. The seven outbreaks are briefly described below.

1830-39: None of the high and dry sites were attacked.

1845-51: Heavy outbreak on the two low sites.

1861-65: The high elevation stands were more infested than low elevation stands.

1870-75: The low elevation stands were more infested than high elevation stands.

1885-93: Dry sites were more severely affected than moister ones.

1944-46: No trend.

1980 - : Outbreak throughout the study area. However, the high stands above all were defoliated.

\section{Comparison with previously identified outbreaks in Colorado and New Mexico}

The comparison of our results with budworm infestations identified by Swetnam and Lynch (1989) in northern New Mexico and Colorado revealed a distinct difference in the duration of reduced growth during outbreaks (Table 3).

Budworm outbreaks lasted longer in the stands covered by the above-mentioned authors. Actually this apparent difference is probably due to the different methods applied. Swetnam and Lynch (1989) determined periods of attack on the basis of ring-width measurements and computation of mean values, whereas we dated abrupt growth reductions. Thus, in our study reductions of $40 \%$ or more were defined as an outbreak period.

The two records exhibit an increased coincidence of outbreak periods in the latter part of the twentieth century (Fig. 4). Nine out of the ten stands investigated by Swetnam and Lynch (1989) fit with the 1940s and 1980s outbreaks observed in our study area. However, the initial years seldom correspond. The budworm infestation of the 1960s only appeared in the Carson National Forest. There was almost no synchronization with the Swetnam and Lynch data reflecting the outbreaks of 1845-1851 and 1854-1862, and no synchronization at all with the $1739-1745$ outbreak. 


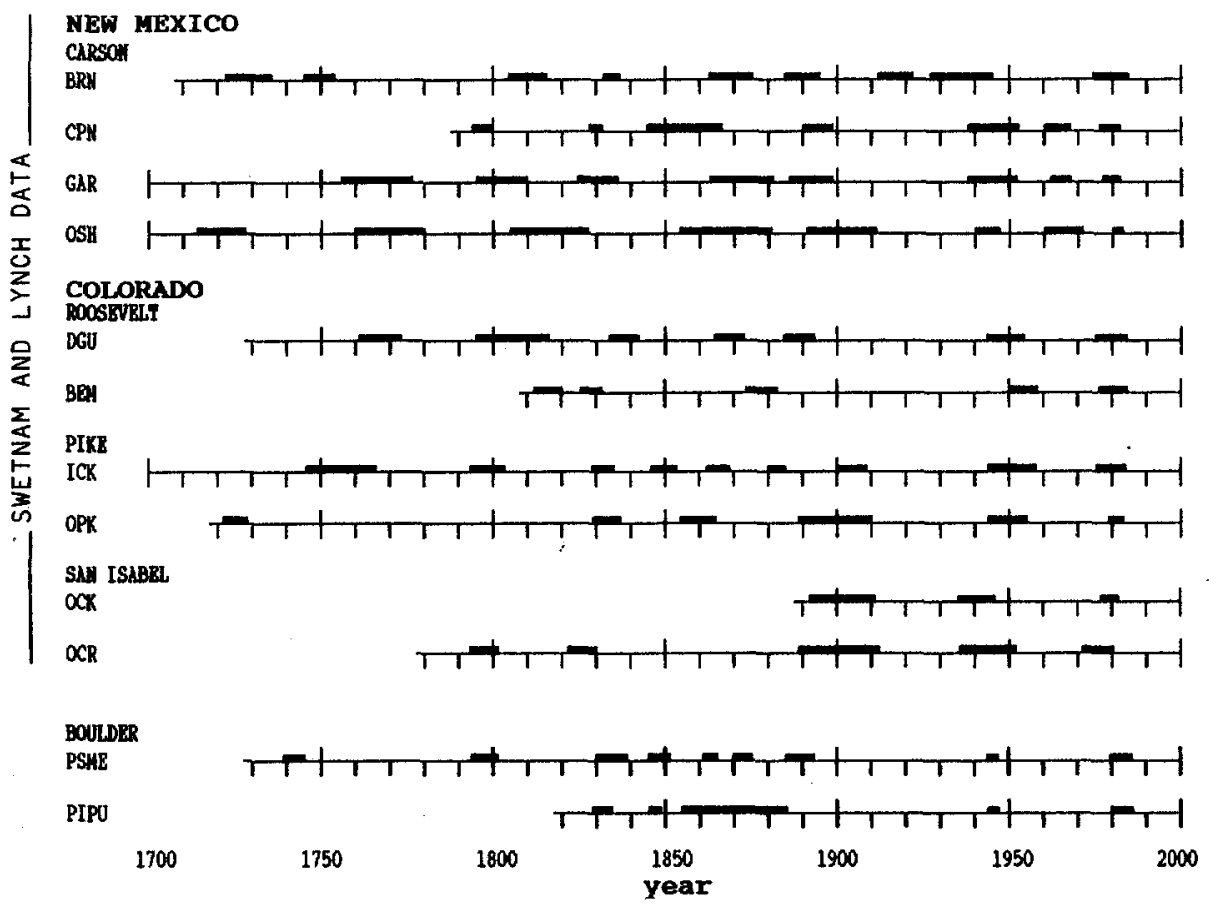

Fig. 4. Periods of reduced growth in Douglas-fir (and blue spruce) stands of New Mexico and Colorado due to western spruce budworm attack. The data from New Mexico and from Roosevelt, Pike and San Isabel, Colorado, were calculated by Swetnam and Lynch (1989). They were graphically compared with our data from Boulder County. TTा outbreaks of western spruce budworm. Swetnam and Lynch data (Douglas-fir only): $B R N=$ Burned Mountain, $C P N=$ Capulin Canyon, $G A R=$ Garcia Park, $O S H=$ Osha Mountain, $D G U=$ Devil's Gulch, $B E M=$ Big Elk Meadows, $I C K=$ Indian Creek, $O P K=$ Ormes Peak, $O C K=$ Oak Creek, and $O C R=$ Ophir Creek. Boulder data: $P S M E=$ Douglas-fir, and $P I P U=$ blue spruce

Table 4. Correspondence between outbreaks in Boulder County and the study areas of Swetnam and Lynch (1989)

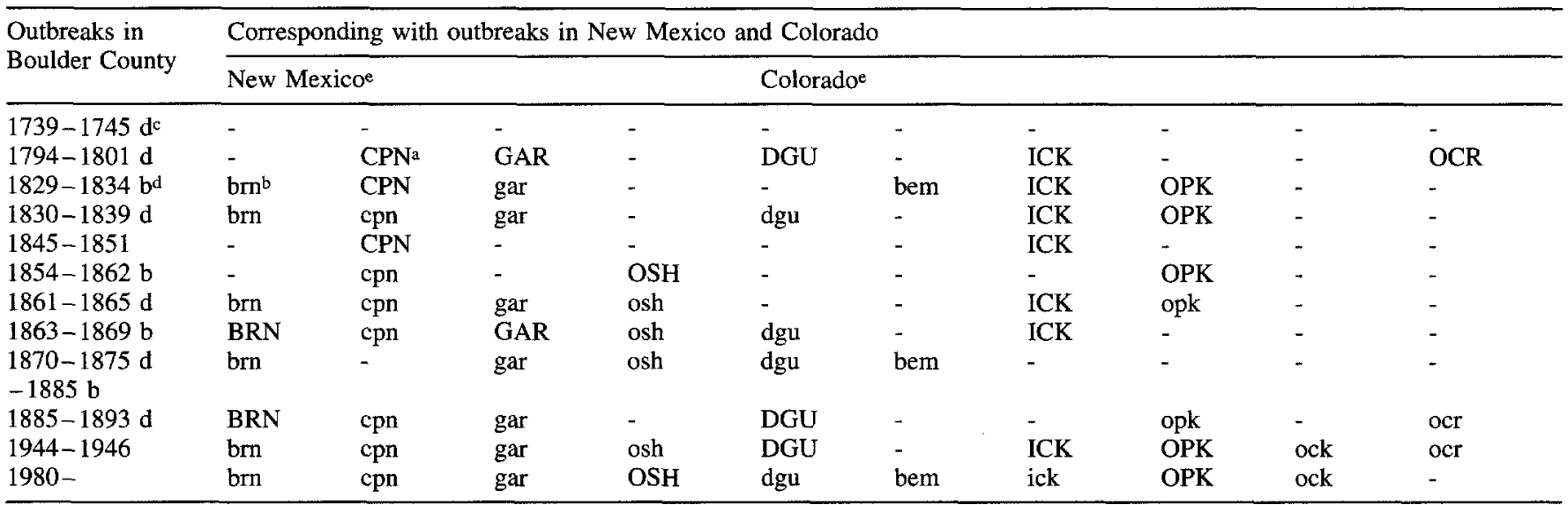

a BOLD = initial year corresponding ( \pm 1 year)

b normal $=$ at least part of outbreak corresponding $(>1$ year $)$

c $\mathrm{d}=$ Douglas-fir only

d $\mathbf{b}=$ blue spruce only

e $\mathrm{BRN}=$ Burned Mountain, $\mathrm{CPN}=$ Capulin Canyon, GAR = Garcia Park, OSH = Osha Mountain, DGU = Devil's Gulch, BEM = Big Elk Meadows, $\mathrm{ICK}=$ Indian Creek, $\mathrm{OPK}=$ Ormes Peak, OCK $=$ Oak Creek, OCR $=$ Ophir Creek

The stands in New Mexico, especially Capulin Canyon (CPN), corresponded better with our data than the Colorado stands (Table 4). However, the comparison of the initial years of outbreaks showed that the Pike National Forest stands Ormes Peak (OPK) and, above all, Indian Creek (ICK) clearly correspond better with the Boulder stands. The closest stand to our research area, Big Elk Meadows (BEM), showed a surprisingly low degree of synchronization.

The different results suggest that the extent, timing and severity of outbreaks of the western spruce budworm depend on different natural and anthropogenic (burning, logging) site disturbances. Only during the most severe outbreaks did the insects seem to invade extensive areas at approximately the same time.

\section{Discussion}

In the recent past as well as today the aperiodic outbreaks of the spruce budworm (Choristoneura fumiferana) and the western spruce budworm (Choristoneura occidentalis) have been affected by a variety of intensive anthropogenic disturbances of the forests (Blais 1983; Carlson et al. 1983; Fellin et al. 1983). Yet the different impacts of past and modern harvesting practices, extended deforestations, fire 
control and insecticide spraying on the development and dispersal of budworm populations are hard to separate from each other. In the study area, greatly increased logging and burning after the discovery of gold in 1859 was probably the factor most strongly affecting montane forest ecosystems (Veblen and Lorenz 1986). The artificially caused shift in species composition towards an increased number of host trees reduced the diversity of stands and appeared to induce a spatial increase of budworm outbreaks. In pre1859 outbreaks such a uniformity was never observed. No satisfactory answer to the accumulation of outbreaks between 1830 and 1900 was found. However, a link between the heavy anthropogenic disturbances during that time and outbreaks is not readily apparent, since the same pattern of outbreaks was also observed in less disturbed areas (Swetnam and Lynch 1989). The relatively long absence of budworm activity in the first part of the twentieth century probably cannot be attributed to deforestations during the mining booms in the latter part of the nineteenth century. In contrast to the upper montane zone of the northern Front Range a massive replacement of Douglas-fir by lodgepole pine after the deforestations did not occur in Boulder County (Clements 1910; Veblen and Lorenz 1986). Moreover, this outbreak-free period is confirmed by Swetnam and Lynch (1989).

The spatial and ecological pattern of defoliation during historical outbreaks was more patchy than during the most recent outbreak. Still, only one correlation between the intensity of budworm attack and the different sites became evident: $80 \%$ of the actually reconstructed outbreaks in Douglas-fir stands in the sub-area Peak to Peak Highway were heavy ones while there were only $37.5 \%$ in the subarea Boulder Canyon; the sites along Peak to Peak Highway were higher and the the stands were more open than in Boulder Canyon. This tendency contradicts results described by other authors (Carlson et al. 1983; Fellin et al. 1983). We do not have an adequate explanation for this discrepancy.

It was not too much of a surprise that the blue spruce stands, most of them being very small and mixed with other host and non-host species, were less severely attacked than the more or less uniform Douglas-fir stands.

Unfortunately, the age of almost half of the stands we analyzed was less than 120 years. Consequently, not all sites could be compared over the whole period of outbreak reconstruction by using eco-diagrams. To gain a closer insight into this issue additional research in undisturbed areas is necessary.

The infestations of the eighteenth and nineteenth centuries tended to be less synchronous among stands in Colorado and New Mexico. However, the outbreaks of the 1940s and 1980s in Boulder County correspond at least partly with outbreaks in nine out of ten study areas worked on by Swetnam and Lynch (1989). An increased synchronization among 24 study sites in the twentieth century was also reported by Swetnam and Lynch (1993). If outbreaks can be synchronized over extended areas the particular budworm population must have been unusually large. This hypothesis, already referred to by the abovementioned authors, suggests that the severity of outbreaks in the twentieth century has increased.
The simple use of the abrupt growth change method, based on visual features, permits a qualitative assessment of historical forest insect attacks. It allows precise dating of the initial year and determination of the duration of growth reductions of western spruce budworm outbreaks. However, weak outbreaks can only be reconstructed when radial growth abruptly decreases more than $40 \%$ (Schweingruber et al. 1990). Taking this restriction into account, the results may be graphically compared with data based on the fundamentally different ring-width measurements (Swetnam and Lynch 1989). However, for the above-mentioned reasons, we consider a statistical comparison of these results to be neither useful nor necessary.

In contrast to the widely applied processing of mean values from measured tree-ring sequences, the abrupt growth change method is based on visually recorded data. The exact number or percentage of samples affected by any tree growth inhibiting or promoting event is taken into consideration. Therefore no unintentional periodicities or mean values which might falsify or even cover the actual data are read into the master plots through possibly unsuitable standardization procedures. This fact is of great significance if the precise date of an event is wanted.

Abrupt growth change data do not fit into commonly used standardized tree-ring programs, which is a major handicap of the method.

Acknowledgement. Many thanks to the University of Colorado which provided financial support for the field work at the Mountain Research Station, Nederland, Colorado, USA.

\section{References}

Blais JR (1962) Collection and analysis of radial growth data from trees for evidence of past spruce budworm outbreaks. For Chron 38: $474-484$

Blais JR (1965) Spruce budworm outbreaks in the past three centuries in the Laurentide Park, Quebec. For Sci 11: 130-138

Blais JR (1983) Trends in the frequency, extent, and severity of spruce budworm outbreaks in eastern Canada. Can J For Res 13: 539-547

Braun-Blanquet J (1964) Pflanzensoziologie, 3. Aufl. Wien

Callahan WG (1986) The Boulder weather log. Upslope Press, Boulder, Colorado

Carlson CE, Fellin DG, Schmidt WC (1983) The western spruce budworm in northern Rocky Mountain forests: a review of ecology, insecticidal treatments and silvicultural practices. In: O'Laughlin J, Pfister RD (eds) Proceedings of the symposium Management of second growth forests, the state of knowledge and research needs. May 1982, Missoula, Montana. School of Forestry, University of Montana, pp 76-103

Christensen K (1987) Tree rings and insects: the influence of cockchafers on the development of growth rings in oak trees. Proceedings of an International Symposium on the Ecological aspects of tree ring analysis. Palisades, pp 142-154

Clements FE (1910) The life history of lodgepole burn forests. USDA For Serv Bull 79: 7-56

Douglass AE (1941) Crossdating in dendrochronology. J For 39: $825-831$

Eckstein D, Hoogesteger J, Holmes R (1990) Insect-related differences in growth of birch and pine at northern tree-line in Swedish Lapland. Holarct Ecol 14: 18-23

Ellenberg H (1982) Vegetation Mitteleuropas mit den Alpen. Ulmer, Stuttgart 
Fellin DG, Shearer RC, Carlson CE (1983) Western spruce budworm in the northern Rocky Mountains: biology, ecology, and impacts. West Wildlands 9: 2-7

Filion L, Jardon Y, Quinty F, Cloutier C, Payette S (1993) Effets de la défoliation par la tenthrède du mélèze (Pristiphora erichsonii) sur la croissance du mélèze (Larix laricina) le long d'un gradient topographique et d'un transect latiduninal au Québec subarctique. In: Les perturbations de croissance des arbres: leurs déclencheurs et leurs effets, résumés de communications, atelier de dendroécologie, station de recherche du centre d'études nordiques, Univ. Laval, Whapmagoostui-Kuujjuarapik, Québec

Geer GA (1975) Der Einfluss des Grauen Lärchenwicklers, Zeiraphera diniana (Gn.) auf den Zuwachs der Lärche, Larix decidua (Mill.) im Oberengadin. Diss Univ Zürich, No. 5499

Hildahl V, Refks WA (1960) Outbreaks of the forest tent caterpillar, Malacosoma disstria $\mathrm{Hbn}$., and their effects on stands of trembling aspen in Manitoba and Saskatchewan. Can Entomol 90: 199-209

Kontic R, Niederer M, Nippel CA, Winkler-Seifert A (1986) Jahrringanalysen an Nadelbäumen zur Darstellung und Interpretation von Waldschäden (Wallis, Schweiz), Ber Eidg Anst Forstl Versuchwesen 283

Landolt E (1977) Ökologische Zeigerwerte zur Schweizer Flora. Veröff Geobot Inst ETH, Stiftung Rübel, 64

Morin H, Laprise D (1990) Histoire récente des épidémies de la Tordeuse des bourgeons de l'épinette au nord du lac Saint-Jean (Québec): une analyse dendrochronologique. Can J For Res 20: $1-8$

Pignatelli O, Bleuler M (1988) Anni caratteristici come indicator di attacchi delle Tortice Grigia del larice (Zeiraphera diniana $\mathrm{Gn}$.). Dendrochronologia 6: $163-170$
Schweingruber FH (1979) Auswirkungen des Lärchenwicklerbefalls auf die Jahrringstruktur der Lärche. Ergebnisse einer Jahrringanalyse mit röntgendensitometrischen Methoden. Schweiz Z Forstwes 130: $1071-1093$

Schweingruber FH, Albrecht H, Beck M, Hessel J, Joos K, Keller D, Kontic R, Lange K, Niederer M, Nippel C, Spang S, Spinnler A, Steiner B, Winkler-Seifert A (1986) Abrupte Zuwachsschwankungen in Jahrringabfolgen als ökologische Indikatoren. Dendrochronologia 4: $125-183$

Schweingruber FH, Eckstein D, Serre-Bachet F, Bräker OU (1990) Identification, presentation and interpretation of event years and pointer years in dendrochronology. Dendrochronologia 8: 9-38

Schwenke W (1978) Die Forstschädlinge Europas, Bd. 3, Schmetterlinge. Parey, Hamburg

Swetnam TW (1986) Radial growth losses in Douglas-fir and white fir caused by western spruce budworm in northern New Mexico: 1700-1983. USDA For Serv SW Reg For Pest Manag Rep 86-2

Swetnam TW, Lynch AM (1989) A tree-ring reconstruction of western spruce budworm history in the southern Rocky Mountains. For Sci 35: $962-986$

Swetnam TW, Lynch AM (1993) Multicentury, regional-scale patterns of western spruce budworm outbreaks. Ecol Monogr 63: 399-424

Veblen TT, Lorenz DC (1986) Anthropogenic disturbance and recovery patterns in montane forests, Colorado Front Range. Physical Geogr 7: 1-24

Vins B, Materna J (1969) Anwendung der Jahrringanalysen zur Auswertung von Betriebsdüngung. Proc Third Int Ertragskundetagung, Prague, pp 303-316 